\title{
鉊一スズ合金メッキ夜の管理と析出物の分析方法
}

\author{
小 西 三 郎* ・ 土 肥 信 康**
}

\section{Control of Lead-Tin Fluoborate Plating Bath and Analysis of the Deposit}

Saburo KONISH* and Nobuyasu DOHI*

Each component in the lead-tin fluoborate plating bath would be quantitatively analyzed by the following procedures simply and correctly.

$\mathrm{Pb}$ : After the excess of EDTA being added to the bath, $\mathrm{Sn}^{++}$was oxidized with $\mathrm{H}_{2} \mathrm{O}_{2}$. Then, the solution was masked with triethanolamine and back titrated with $\mathrm{Zn}^{++}$at $\mathrm{pH}=10$ using $\mathrm{BT}$ as indicator.

$\mathrm{Sn}^{++}$: After $\mathrm{Pb}$ was precipitated with $\mathrm{H}_{2} \mathrm{SO}_{4}$, titrated by iodometry.

Free $\mathrm{HBF}_{4}$ and Free $\mathrm{H}_{3} \mathrm{BO}_{3}$ : After $\mathrm{Pb}$ was precipitated with $\mathrm{Na}_{2} \mathrm{SO}_{4}$, free $\mathrm{HBF}_{4}$ was determined by alkaline titration with $\mathrm{pH}$-meter to $\mathrm{pH}=3.5$ as the end point. Then, $\mathrm{pH}$ was made to 7.0 , mannite was added to it, and free $\mathrm{H}_{3} \mathrm{BO}_{3}$ was determined by alkaline titration to $\mathrm{pH}=8.0$ as the end point.

Hydroquinone: Precipitate was filtered off from the solution after the determination of $\mathrm{HBF}_{4}$ and $\mathrm{H}_{3} \mathrm{BO}_{3}$ and titrated with $\mathrm{Ce}^{+4}$ using ferroin as indicator after made acidic with $\mathrm{H}_{2} \mathrm{SO}_{4}$.

Lead and tin in the deposit could be determined by the following procedures.

$\mathrm{Pb}$ : Lead-tin plated layer was dissolved by a remover such as Enstrip TL and the excess of EDTA was added to the solution. Then, tin was masked with triethonolamine and back titrated with $\mathrm{Zn}$ at $\mathrm{pH}=10$.

$\mathrm{Sn}$ : The above solution wa made acidic with $\mathrm{HCl}$ and back titrated with $\mathrm{Zn}$ at $\mathrm{pH}=5$ in the warm state using $\mathrm{PV}$ as indicator to determine $\mathrm{Sn}+\mathrm{Pb}$. Then, $\mathrm{Sn}$ was calculated.

\section{1. まえがき}

鉛一スズ合金メッキは, 多くの工業用目的のために使 用される。その主な用途としては，4１0\%（特に 6\%） のスズを含有した合金メッキは鉄の耐食被覆に 用いら れ，7〜10\% のスズ合金メッキはべアリングの表面に, また 10〜60\% のスズを含んだいわゆるハンダメッキは， 固形ハンダを使用することなしにハンダ付けが可能であ るため, 電子工業部品およびその他の部品の組立てに便 利である1”。最近，筆者の一人である土肥2により，外 国にもその例を見ない完全鏡面光沢の鉛一スズ合金メッ キが開発され，その用途はさらに拡大されつつある。そ の他の利用としては, ハンダのスクラップより，鉛拉よ びスズの再生にも用いられる1。

これらの鉛一スズ合金メッキは, 主にホウフッ化浴か らメッキされるが，ある組成の鉛一スズ合金メッキをう るためには、メッキ夜をよく管理する必要がある。ホウ

* 大阪府立工業奖励館東大阪分館 (大阪府布施市高井田 中) Industrial Research Institute Osaka Prefecture **兵庫県工業奖励馆 (兵庫県神戸市須磨区上手崎町) Industrial Research Institute Hyogo Prefecture
フッ化鉛一スズ合金メッキ液中のスズは, ヨード法で比 較的簡単に分析することができるが，鉛の分析は重量法 によらなければならない3。一般に，ホウフッ化鉛一ス ズメッキ夜の分析法については，ホウフッ化鉛またはホ ウフッ化スズメッキ液の分析方法を参照としてある゙け れども問題点が多い。避離ホウフッ酸, 括よび遊離ホウ 酸についてる同様である。

析出物の組成の決定法としては，鉛メッキと鉛一スズ 合金メッキの電気化学当量の相違により求める方法1)5) があるが，析出物の組成を簡単な方法で化学分析により 求める方法は知られていない。ゆえに筆者らは, EDTA を用いて，簡単に合金メッキ液中の鉛，析出物中の鉛お よびスズを分析する方法を検討し，良好な結果をうるこ とができた。その他, 遊離ホウフッ酸, 遊離ホウ酸およ び添加剤についても検討したので，これらについても報 告する。

\section{2. 鉊一スズ合金メッキ液の分析法}

\section{2-1 鉊6)}

使用試薬

0.05 M EDTA 標準溶液 
$0.05 \mathrm{M}$ 硫酸亜鉛硒準溶液 $30 \%$ 過酸化水素水

$1 \mathrm{M} / l(282 \mathrm{~g} / l$ ロッセル塩溶液 $20 \%$ トリエタノールアミン溶液

$\mathrm{pH} 10$ 緩衝溶液 (塩化アンモニウムーアンモニア) BT 指示薬

\section{分析操作法}

1）鉛一スズ合金メッキ液 $2 \mathrm{~m} l$ をピペットで正確にと り, これに $1 \mathrm{M} / l$ ロッセル塩溶液 $5 \mathrm{ml}$ を加えたの ち, $30 \%$ 過酸化水素水約 $1 \mathrm{~m} l$ を加える。

2）純水 $100 \sim 150 \mathrm{ml}$ と $20 \%$ トリエタノールアミン 溶液 $5 \mathrm{ml}$ を加之る。

3） $0.05 \mathrm{M}$ EDTA 標準溶液 $25 \mathrm{ml}$ を正確に加えたの ち, pH 10 の緩衝溶液 $10 \mathrm{ml}$ を加立る。

4） BTを指示薬として, 過剩の EDTA 亜鉛標準溶液で逆滴定する。終点は青色が赤色になっ たところである。

5) 剧算

$$
\mathrm{Pb} \mathrm{g} / l=0.01036 \times(25 \mathrm{~m} l
$$
$-0.05 \mathrm{M}$ 硫酸覀鉛 $\mathrm{m} l) \times \frac{1000}{2}$

$\mathrm{Pb}\left(\mathrm{BF}_{4}\right)_{2} \mathrm{~g} / l=0.01904 \times(25 \mathrm{~m} l$ $-0.05 \mathrm{M}$ 硫酸亜鉛 $\mathrm{m} l) \times \frac{1000}{2}$

この方法で鉛一スズ合金メッキ液中の鉛を分析した結 果は, 重量で行なった場合3)とよく一致した。

\section{2-2 ス ス}

鉛一スズ合金メッキ液中の $\mathrm{Sn}^{+2}$ の分析法については, とくに記載された文献はなく，ただホウフッ化スズメッ キ液中の $\mathrm{Sn}^{+2}$ と同様の方法で, ヨード法で行な5よう に書かれている4)。しかし，鉛一スズ合金メッキ液中の $\mathrm{Sn}^{+2}$ をヨード法で分析する場合, ホウフッ化スズメッ キ液中 $\mathrm{Sn}^{+2}$ を分析する場合のように，塩酸々性でョー ドの標準溶液でデンプンを指示薬として滴定した場合, ヨウ素イオンと鉛とが反応して黄カッ色のヨウ化鉛を生 成し，終点を不明蹽にする。

この場合に, 塩酸の代りに硫酸弪使用すると良好な結 果がえられる。すなわら, 鉛一スズ合金メッキ液に硫酸 を添加すると，白色の硫酸鉛が沈殿するが，これにヨウ 素イオンが入ってもヨウ化鉛が生成することはなく，し たがって，終点は非常に明瞭である。

\section{2-3遊離ホウフッ酸および遊離ホウ酸 \\ 使用試薬}

$1 N$ 水酸化ナトリウム標準溶液

$30 \%$ 硫酸ナトリウム $\mathrm{Na}_{2} \mathrm{SO}_{4} \cdot 10 \mathrm{H}_{2} \mathrm{O}$ 溶液 マニット

\section{装}

$\mathrm{pH} メ ー タ$

\section{分析操作法}

1) メッキ液 $10 \mathrm{~m} l$ をピペットで正確にとり，これに 純水 $100 \mathrm{~m} l$ と $30 \%$ 硫酸ナトリウム溶液 $10 \mathrm{~m} l$ を加 える。

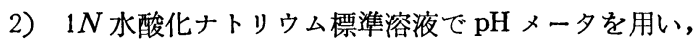
$\mathrm{pH} 3.5$ を終点として滴定する。

3) 計 算

$\mathrm{HBF}_{4} \mathrm{~g} / l=0.0878$

$$
\times 1 N \text { 水酸化ナトリウム } \mathrm{m} l \times \frac{1000}{10}
$$

4）つづいて水酸化ナトリウム標準溶液を徐々に滴下 し，pH を正碓に7.0にする。

5）マニット約 $5 \mathrm{~g}$ を加え，よくカクハンしたのり， $1 N$ 水酸化ナトリウム標準溶液で滴定する。終点は $\mathrm{pH}$ 8.0 (または, フェノールフタレインを指示薬として 使用した場合には赤色になったところ）である。 $\mathrm{pH}$ 7.0 以後に使用した $1 N$ 水酸化ナトリウム標準溶液の $\mathrm{m} l$ を読さ。

6) 計 算

$$
\begin{aligned}
& \mathrm{H}_{3} \mathrm{BO}_{3} \mathrm{~g} / l=0.06184 \\
& \times 1 N \text { 水酸化ナトリウム } \mathrm{m} l \times \frac{1000}{10}
\end{aligned}
$$

ホウフッ酸は次の反応式に示したように，4 $\mathrm{mol}$ のフ ッ化水素と $1 \mathrm{~mol}$ の小ウ酸が反応することによりえられ る。

$$
4 \mathrm{HF}+\mathrm{H}_{3} \mathrm{BO}_{3} \rightarrow \mathrm{HBF}_{4}+3 \mathrm{H}_{2} \mathrm{O}
$$

第 1 図のAは, 試薬特級のフッ化水素の滴定曲線であ る。これに上式に当量のホウ酸を添加すれば， Bのホウ フッ酸の滴定曲線がえられる。この場合の反応は，滴定 曲線からも分るように

$$
\mathrm{HBF}_{4}+\mathrm{NaOH} \rightarrow \mathrm{NaBF}_{4}+\mathrm{H}_{2} \mathrm{O}
$$

でありこの反応は $\mathrm{pH} 3.5$ 以上に拈いて完結する。し たがって，遊離ホウフッ酸の分析のための指示薬として は, $\mathrm{pH} 3.5$ 以上で変色する指示薬, たとえばメチールオ レンジ7) が必要であり, クレゾールレッドなどの $\mathrm{pH} 4$ 以下で変色する指示薬 ${ }^{8)}$ の使用はよくない。ホウフッ 酸と水酸化ナトリウムとの反応については, $\mathrm{HBF}_{4}$, $\mathrm{HBF}_{3}(\mathrm{OH})$ 抌よび $\mathrm{HBF}_{2}(\mathrm{OH})_{2}$ などの hydroxyfluoboric acid の生成に基ついて中和されるす)といわれているが， これらは第 1 図の B にみられるように正しくないと思 5 。

これにさらに過剩のホウ酸を加えた場合には，第 1 図 のC以下の滴定曲線となる。これらの滴定曲線からる分 るように, 遊離のホウフッ酸の中和は $\mathrm{pH} 3.5$ に打いて 完結するが，これに過剩のホウ酸が存在した場合には， $\mathrm{pH}$ 4〜 7 に沶いてある種の化合物， $\mathrm{pH} 7$ 以上に沶いて

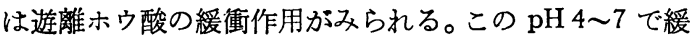
衝作用のある化合物は未確認であるが，ホウ酸飽和量ま では，ホウ酸量に比例した量の化合物が存在する。しか 


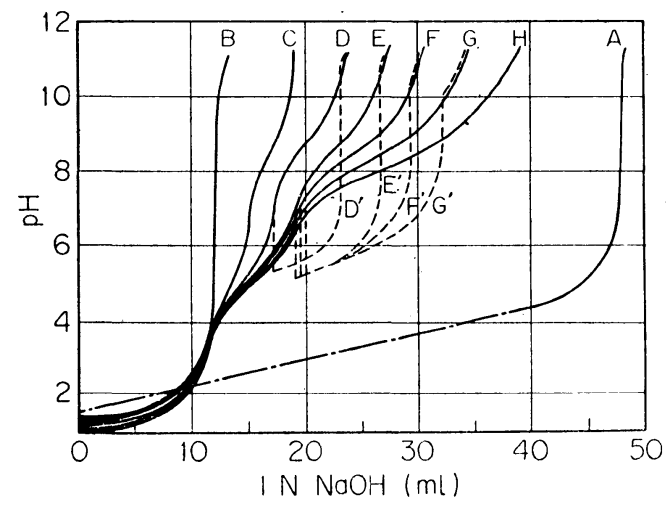

し，ホウ酸を過飽和 (滴定条件では完全に溶解している) にしても，その量はホウ酸飽和つ時と変らない。 $\mathrm{pH} 7$ でマニットを添加すれば $\mathrm{pH}$ は低下し，つつい て $\mathrm{pH} 8$ を終点として水酸化ナトリウムで滴定すれば, 遊離ホウ酸を求めることができる。これらを図示すれば， 第2図のようになる。

市販のホウフッ酸中には，必ず遊倣ホウ酸が含まれて いるが，その量は一定ではない。この遊離ホウ酸が，木 ウフッ酸の Hydroxyfluoboric acidへの加水分解を防止:

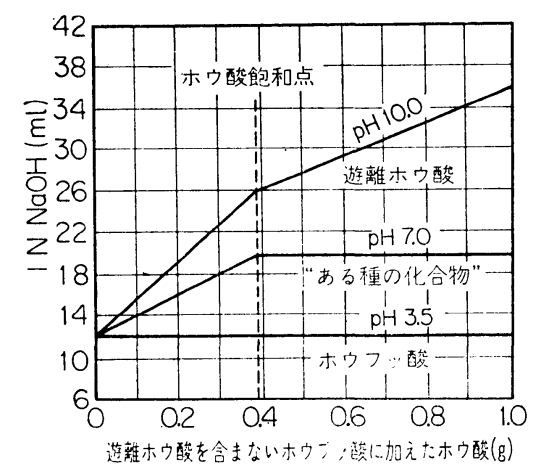

第 2 図ホウフッ酸中のホウ酸

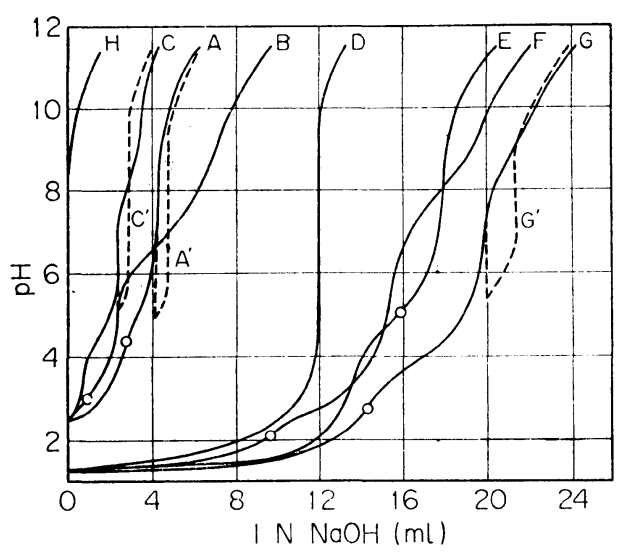

A ； 市肘特級フッ化水索水 $2 \mathrm{~m} l$

B ; Ar当量の木ウ酸を添加 $\left(\mathrm{HBF}_{4}\right)$

C ; BK $0.2 \mathrm{~g}$ のホウ酸を添加

D ; BK $0.3 \mathrm{~g}$ のホウ酸を添加

$\mathrm{D}^{\prime} ; \mathrm{pH} 7$ K打いてマニツトを添加

$\mathrm{E} ; \mathrm{B}$ K小门酸を能和

$\mathrm{E}^{\prime} ; \mathrm{pH} 7$ に批いてマニットを添加

F； BK $0.5 \mathrm{~g}$ ホウ酸を添加（過舭和）

$\mathrm{F}^{\prime} ; \mathrm{pH} 7$ に怙いてマニットを添加

G ; BR $0.75 \mathrm{~g}$ のホウ酸を添加（過能和）

$\mathrm{G}^{\prime} ; \mathrm{pH} 7$ に怙いてマニットを添加

H； BK $1 \mathrm{~g}$ のホウ酸を添加（過饱和）

第 1 図フッ化水䊶とホウフッ酸の湤定曲線

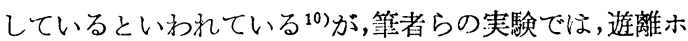
ウ酸を含まないホウフッ酸を相当長く放置しておいてる Hydroxyfluoboric acid の生成を認めなかった。また市販 のホウフッ酸中には, 5 12\%の monohydroxyfluoboric acid が含有されているといわれている9 が，これは筆者 らがいっているホ门酸過剩の場合の “市る種つ化合物” ではないかと思われる。

以上はホウフッ酸単独溶液の場合であるが，これに金 属イオンが存在した場合には, さらに間題が多くなる。

第3〜4図は,遊離ホウ酸を含まないホウフッ酸とホウ 酸を飽和したホウフッ酸 (第 1 表) $200 \mathrm{~m} l$, 市肘ホウフ ッ化スズ溶液 $50 \mathrm{~m} l$, ホゥフッ化鉛溶夜 $100 \mathrm{~m} l$ (第 2 表) でメッキ液を作り， pHメータを用いて滴定した場合の 結果である。第 1 表は, 第 1 図の滴定曲線より計算した 結果であり，第 2 表のホウフッ化スズおよび鉛溶液の分 析は次のような方法で行なった。ホウフッ化スズ溶液中 のスズはヨード法, 遊離のホウフッ酸は $\mathrm{pH} 3.5$ を終点 として水酸化ナトリウムで滴定した。この条件ではスズ は沈殿しない。遊離ホウ酸は, 前記の分析法と同様の方 法で, $\mathrm{pH} 7$ 亿抽いてマニットを添加して求めた。ホウ フッ化鉛メッキ液中の鉛は EDTA 法6), 遊離ホウフッ酸

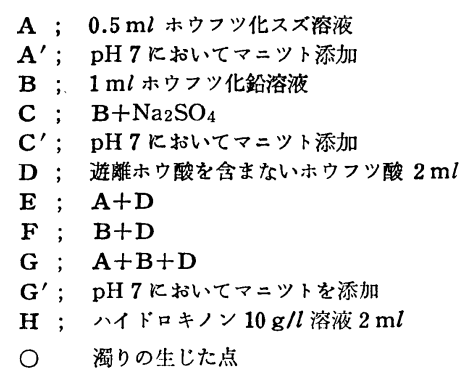

第3図 ホウフッ化スズ括よびホウフッ化鉛泭液と これに遊離ホウ酸を含まないホウフッ酸を 加えた場合の滴定曲線 


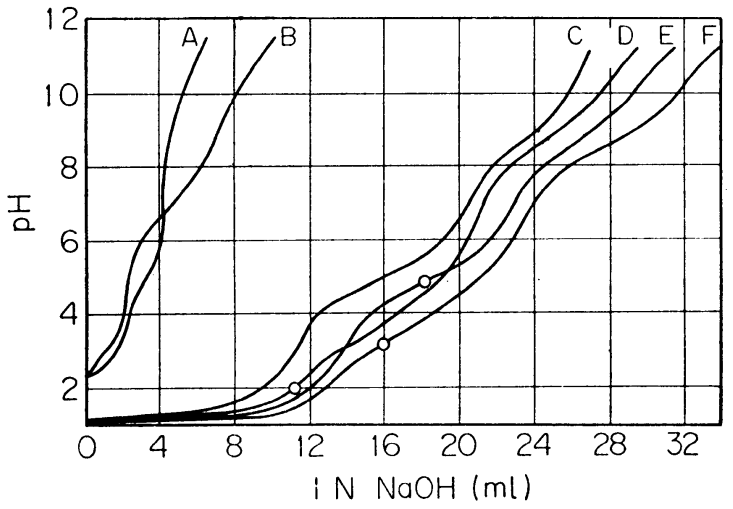
$A ； 0.5 \mathrm{~m} l$ ホウフッ化スズ溶液
B ； $1 \mathrm{ml}$ ホウフツ化鉛溶液
C ； ホウ酸を能和したホウフツ酸 $2 \mathrm{~m} l$
D ; $\mathbf{A}+\mathbf{C}$
E; $; \mathrm{B}+\mathrm{C}$
$\mathrm{F} ; \mathrm{A}+\mathrm{B}+\mathrm{C}$
○濁りの生した点

第 4図 ホウフッ化スズ抢よびホウフッ化鉛溶液と これにホウ酸を飽和したホウフッ酸を加え た場合の滴定曲線

は， pH 3.5 を終点とするアルカリ滴定では多量の水酸 化鉛が沈殿し誤差となるので，硫酸ナトリウムを加えて 鉛を沈殿させたのち， pH 3.5 を終点としてアルカリ滴 定した。遊離ホウ酸も，鉛を沈殿せしめた溶液で上記の 方法により定量した（第 2 図参照）。

ホウ酸を含まないホウフッ酸に，上記のホウフッ化鉛 溶液を加えた場合には, 添加ホウフッ酸 (ホウフッ化鉛 溶液中の遊離ホウフッ酸を含む）に当量よりも少ないア ルカリ量で濁りを生じ，ホウフッ化スズ溶夜を加えたと きには多いアルカリ量で濁りを生じる。鉛とスズを同時 に加えた場合には，両者の中間で濁りを生じる。ホウ酸 を飽和したホウフッ酸中でも，ほぼ同様の現象がみられ るが，一般にアルカリの多い点で濁りを生じる。特に， スズのみを添加した場合には，相当高い $\mathrm{pH}$ ，すなわち $\mathrm{pH} 5$ 付近において初めて濁りを生じる。

ホウフッ化メッキ液中の遊離のホウフッ酸の分析は, 通常指示薬として，クレゾールレッドを用いたり，濁り

第 1 表 試薬特級フッ酸にホウ酸を 加えて作ったホウフッ酸

\begin{tabular}{|c|c|c|c|}
\hline & フッ酸 & $\begin{array}{l}\text { 遊離木ウ酸を } \\
\text { 含まないホウ } \\
\text { フッ酸 }\end{array}$ & $\begin{array}{l}\text { ホウ酸飽和の } \\
\text { ホウフッ酸 }\end{array}$ \\
\hline 比 & 1.13 & 1.24 & 1.26 \\
\hline 酸 & $\left|\begin{array}{r}\mathrm{HF} 472 \mathrm{~g} / \mathrm{l} \\
(42.5 \%)\end{array}\right|$ & $\begin{array}{c}\mathrm{HBF}_{4} 526 \mathrm{~g} / \mathrm{l} \\
(42.5 \%)\end{array}$ & $\begin{array}{r}\mathrm{HBF}_{4} 526 \mathrm{~g} / \mathrm{l} \\
(42.5 \%)\end{array}$ \\
\hline 遊離ホウ酸 & & $\begin{array}{l}0 \mathrm{~g} / \mathrm{l} \\
(0 \%)\end{array}$ & $\begin{array}{c}185 \mathrm{~g} / \mathrm{l} \\
(14.7 \%)\end{array}$ \\
\hline
\end{tabular}

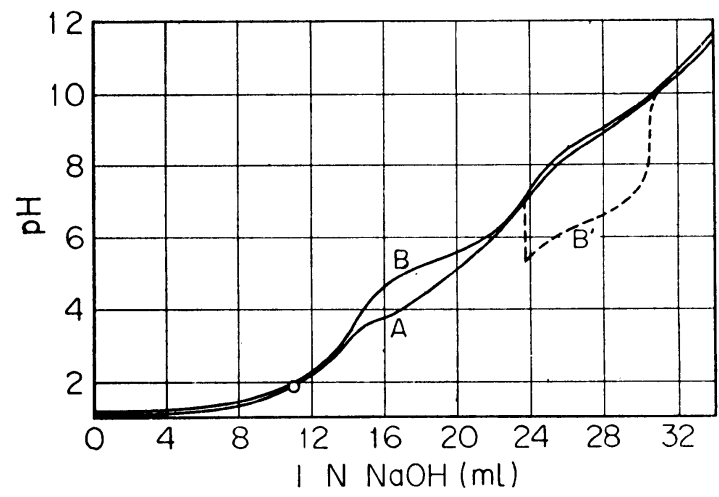

$50 \mathrm{~m} l / l$

$\left\{\begin{array}{lc}\text { ホウフツ化鉛溶液 } & 100 \mathrm{ml} / l \\ \text { ホウフツ酸 (遊離ホウ酸なし) } & 200 \mathrm{~m} l / l \\ \text { ホウ酸 } & 37 \mathrm{~g} / l \\ \text { ヘブトン } & 3 \mathrm{~g} / l \\ \text { ハイドロキノン } & 10 \mathrm{~g} / l\end{array}\right.$

$10 \mathrm{ml}$

B ; $\mathrm{A}+\mathrm{Na}_{2} \mathrm{SO}_{4}$

$\mathbf{B}^{\prime}$; pH 7 においてマニツト添加

○濁りを生した点

第 5 図 ホウフッ化スズ一鉛メッキ液の滴定曲線

を生じた点を終点とする方法などが用いられているが， クレゾールレッドは $\mathrm{pH}$ が $0.2 \sim 1.8$ で赤〜黄に変色す るので，指示薬としては不適当であり，また濁りを終点 とする方法は不明瞭であるのみならず，上述のように金 属の種類と量, 添加した水の量および添加剤の種類によ っても異なる。

しかしながら上述のように，鉛を硫酸塩で沈殿せしめ てのち, $\mathrm{pH}$ メタを用いて $\mathrm{pH} 3.5$ を終点として滴定 すれば，満足すべき結果が得られる（第5図）。

遊離ホウ酸は，金属分を含まない場合と同様の方法で 求めることができる。鉛一スズホウフッ化浴中の遊離ホ ウ酸の飽和濃度は, 遊離ホウフッ酸の濃度によって異な るが, $42.5 \%$ ホウフッ酸 $200 \mathrm{ml} / l$ の場合には遊離ホウ 酸の濃度は $75 \mathrm{~g} / l$ にもなる。一般に ホウ酸の溶解度は 小さく、ニッケルメッキ液などにおいてもその溶解度は 35〜40 g/l であるのに，この昜合には 75〜80 g/l にも

第 2 表 ホウフッ化スズ括よび鉛溶液

\begin{tabular}{ll|c|c}
\hline \hline & & ホウフッ化スズ溶液 & ホウフッ化鉛溶液 \\
\hline 比 & 重 & 1.54 & 1.92 \\
\hline 金 & 属 & $\mathrm{Sn}^{+2} 267 \mathrm{~g} / l(17.3 \%)$ & $\mathrm{Pb} 591 \mathrm{~g} / l(30.8 \%)$ \\
\hline 金 属 & 塩 & $\mathrm{Sn}\left(\mathrm{BF}_{4}\right)_{2} \begin{array}{r}658 \mathrm{~g} / l \\
(42.5 \%)\end{array}$ & $\mathrm{Pb}\left(\mathrm{BF}_{4}\right)_{2}\left(\begin{array}{l}1090 \mathrm{~g} / l \\
(56.8 \%)\end{array}\right.$ \\
\hline $\begin{array}{l}\text { 遊離ホウフ } \\
\text { 酸 }\end{array}$ & $360 \mathrm{~g} / l(24.0 \%)$ & $96 \mathrm{~g} / l(5.0 \%)$ \\
\hline 遊離ホウ酸 & $92 \mathrm{~g} / l(6.0 \%)$ & $31 \mathrm{~g} / l(1.6 \%)$ \\
\hline \hline
\end{tabular}




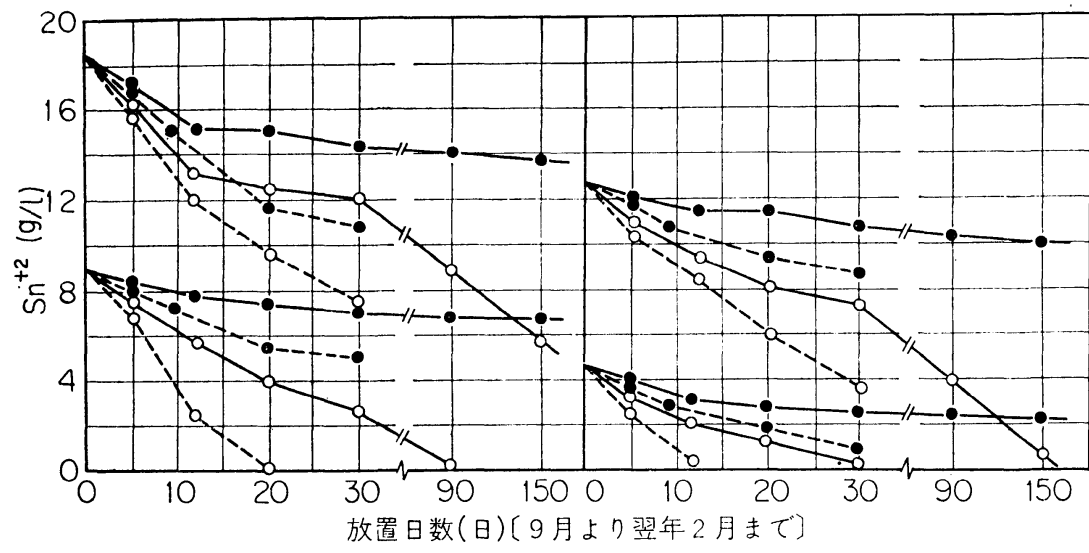

浴組成

$\mathrm{Sn}^{+2} 18.4 \mathrm{~g} / \mathrm{l}, 12.7 \mathrm{~g} / \mathrm{l}, 8.9$

$\mathrm{g} / \mathrm{l}$ および $4.6 \mathrm{~g} / \mathrm{l}$

$\mathrm{Pb} \quad 59.1 \mathrm{~g} / \mathrm{l}$

市販ホウフツ酸 $200 \mathrm{ml} / l$

添加ホウ酸 $25 \mathrm{~g} / l$

ペプトン $3 \mathrm{~g} / \mathrm{l}$

ハイドロキシン $0 \mathrm{~g} / \mathrm{l}$ 扰よ゙

$10 \mathrm{~g} / \mathrm{l}$

第 6 図 ホウフッ化鉛一スズメッキ液中の $\mathrm{Sn}^{+2}$ の減少量

なる。これは，第1表からす分るように，ホウ酸を飽和 したホウフッ酸中には, すでに $185 \mathrm{~g} / \mathrm{l}$ もの遊離ホウ酸 を含んでいる。この溶液で， $200 \mathrm{ml} / l$ のホウフッ酸を 含んだメッキ液を作れば，これにはすでに $37 \mathrm{~g} / l$ の進 離ホウ酸を含んだメッキ液を作ったことになる。このメ ッキ夜に，さらにホウ酸を添加すれば，さらにホウ酸は 溶解する。この後者のホウ酸量は $38 \mathrm{~g} / l$ である。この 值は, 普通のメッキ液中のホウ酸の溶解度に近い。これ らのことからも, ホウ酸はホウフッ酸と何らかの反応を し, “ある種の化合物”を形成していると考えられる。

ホウフッ化メッキ液の $\mathrm{pH}$ をガラス電極 $\mathrm{pH}$ メータで 測定する場合には, ホウフッ化イオンにより，ガラス電 極が侵されるので信頼でさない゙)といわれているが，本 実験に括いては，ホウフッ酸を含んだ多くのメッキ液に ついて滴定曲線を求めたが，そのよ5な現象は見られな

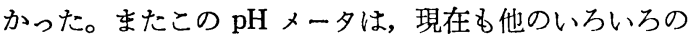
実験に使用しているが，別に問題はない。しかし，ホウ フッ化メッキ液をガラス瓶に入れて長らく放置して尉く と, やはりガラスは侵されるので, ホウフッ化メッキ液 の $\mathrm{pH}$ をガラス電極で测定する場合には，できるだけ速 やかに测定し，よく洗浄しておくことが望ましい。

$\mathrm{pH}$ メーターを使用しないで， $\mathrm{pH}$ 指示薬が使用でき れば有利であるので, $\mathrm{pH} 3.8$ で変色するメチルオレン ジーキシレンシアノール FF, pH 7.1 で変色するニュー トラルレッドーブロムチモールブルーなどの中和滴定用 混合指示薬を使用してみたが, 結果は良好ではなかった。

\section{2-4 ハイドロキノン}

ハイドロキノンのホウフッ化鉛一スズメッキ液への添 加は, 第 6 図に示したよ5にメッキ液中の $\mathrm{Sn}^{+2} \rightarrow \mathrm{Sn}^{+4}$ の酸化を防止するのみならず, 析出物中のスズの増加に 役立つ(第 7図)。ゆえに，ホウフッ化鉛一スズメッキ 液にハイドロキノンを添加することは，鉛一スズメッキ にとって非常に有利となる。
スズメッキ液中のクレゾールまたはフェノールなどは， bromination 法により正確に分析できるといわれている が，その操作法は明記されていない11)。また，ホウフッ 化鉛一スズメッキ夜中のレゾルシノールも Bromination

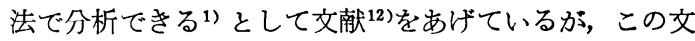
献には該当するものはみられなかった。

ゆえに筆者らは，JISによるハイドロキノンの分析 法 ${ }^{13)}$ を，ホウフッ化鉛一スズメッキ液に応用した。

\section{使用試薬}

$0.1 N$ 硝酸セレニウムアンモニウム栖隻溶液 $120^{\circ} \mathrm{C}$ で乾燥した $\mathrm{Ce}\left(\mathrm{NO}_{3}\right)_{4} \cdot 2 \mathrm{NH}_{4} \mathrm{NO}_{3}$ 約 $55 \mathrm{~g}$ を $30 \mathrm{~m} l / l$ 硫酸溶液 $1 l$ に溶解する。標定は $0.1 N$ 硫 酸第 1 鉄アソモニウム標準溶液でフェロインを指示 薬として行なった。

フェロイン (Ferroin) 溶液

$1.624 \mathrm{~g}$ の o-Phenanthrolin 塩酸塩と硫酸第 1 鉄 $0.695 \mathrm{~g}$ を純水 $100 \mathrm{~m} l$ 溶解する。

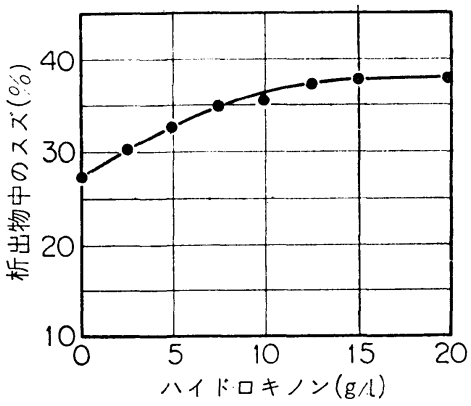

浴組成およびメツキ条件

$\begin{array}{lr}\mathrm{Sn}+2 & 14.5 \mathrm{~g} / l \\ \mathrm{~Pb} & 54.0 \mathrm{~g} / l \\ \text { 市販ホウフツ酸 } & 200 \mathrm{ml} / l \\ \text { 添加ホウ酸 } & 25 \mathrm{~g} / l \\ \text { ペプトン } & 3 \mathrm{~g} / l \\ \text { ハイドロキノン } & 0 \sim 20 \mathrm{~g} / l \\ D_{K} 3 \mathrm{~A} / \mathrm{dm}^{2}, & \text { 浴温 } 30^{\circ} \mathrm{C}\end{array}$

第7図ハイドロキノンの影響 
$6 N$ 硫酸

\section{分析方法}

1）遊離ホウフッ酸と遊離ホウ酸定量後の試料溶液を, メスフラスコを用いて正確に $200 \mathrm{~m} i$ としたのち，乾 いたロートとロ紙で $100 \mathrm{ml}$ のメスフラスコにロ過す る。

2) このロ液に $6 N$ 硫酸 $10 \mathrm{ml}$ とフェロイン溶液数滴 を加え, $0.1 N$ 硝酸セレニウムアンモニウム標準溶液 で滴定する。終点は, 橙色が淡青色になったところで ある。

3) 計 算

$\mathrm{C}_{6} \mathrm{H}_{4}(\mathrm{OH})_{2} \mathrm{~g} / l=0.005506 \times(0.1 N$ 硝酸セV ニウムアンモニウム $\mathrm{m} l \times 2) \times 1000$

この方法では $\mathrm{Ce}^{+4}$ によりメッキ液中の $\mathrm{Sn}^{+2}$ は $\mathrm{Sn}^{+4}$ に酸化され $\mathrm{Ce}^{+4}$ を消費するので,メッキ液中の $\mathrm{Sn}^{+2}$ は 完全に除去しておかねばならない。この方法については いろいろ検討したが，上記のよ5に遊離ホウフッ酸と遊 離ホウ酸定量後の試料溶液を利用するのがもっとも便利 である。

この分析方法を応用して，第 6 図に示した約 3 ケ月間 放置して $\mathrm{Sn}^{+2}$ が減少したメッキ液について，ハイドロ キノンを分析したが，第３表に示したよ5に，ハイドロ キノンはほとんど減少していないことが分った。すなわ ち,メッキ液中のハイドロキノンは, 自分自身が酸化さ れて, $\mathrm{Sn}^{+2}$ の $\mathrm{Sn}^{+4}$ への酸化を防止しているのではな く, 自分自身も酸化しないで, $\mathrm{Sn}^{+2}$ の $\mathrm{Sn}^{+4}$ への酸化を 防止している。
第 3 表 メッキ液中のハイドロキノン

\begin{tabular}{|c|c|c|}
\hline 試料溶液 & $\begin{array}{c}\text { ハ1ドロキノン } \\
\text { 添加浱度 }\end{array}$ & 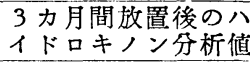 \\
\hline A & $10 \mathrm{~g} / \mathrm{l}$ & $9.9 \mathrm{~g} / \mathrm{l}$ \\
\hline $\mathrm{B}$ & $10 \mathrm{~g} / \mathrm{l}$ & $10.0 \mathrm{~g} / \mathrm{l}$ \\
\hline $\mathrm{C}$ & $10 \mathrm{~g} / \mathrm{l}$ & $9.8 \mathrm{~g} / l$ \\
\hline $\mathrm{D}$ & $10 \mathrm{~g} / \mathrm{l}$ & $9.9 \mathrm{~g} / l$ \\
\hline
\end{tabular}

\section{3. 析出物の組成の決定と 平均厚サの測定}

析出物中の鉛とスズとの比は，メッキ液中の鉛とスズ との組成に閵係のあることはもちろんのことである（第 8 図)。メッキ液中の遊離ホウフッ酸, ホウ酸には大きな 影響はないけれども, 添加剤执よび電流密度などによっ ても大きく変化する(第 9, 10 図)。

一般に, メッキ液の分析結果からは析出物の組成を推 測することはできるが，正確にはその析出物を分析して みる必要がある。

\section{3-1 鉊一スズ合金析出物組成の分析}

\section{使用試薬}

メッキハク離阂

水酸化ナトリウム $100 \mathrm{~g} / l, \mathrm{o}-$ ニトロ安息香酸 $50 \mathrm{~g} / \mathrm{l}$ または, エンストリップ TL $150 \mathrm{~g} / l$ (エンソン社, 鉛一スズ合金メッキハク離剂)

0.05 M EDTA 標準溶液

$0.05 \mathrm{M}$ 硫酸覀鉛標準溶液

$20 \%$ トリエタノールアミン溶液

塩化アンモニウム（固体）

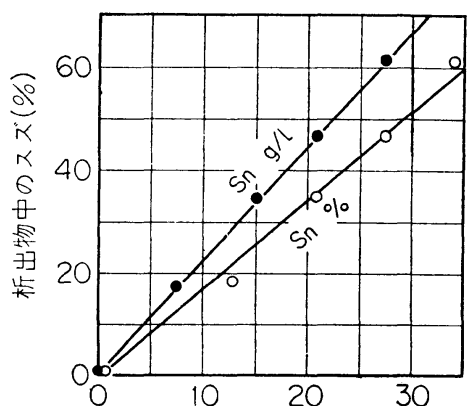

浴中のスズ(g/および\%)

$\begin{array}{lc}\text { 浴組成およびメツキ条件 } & \\ \mathrm{Sn}^{+2} & 0 \sim 27.5 \mathrm{~g} / l \\ \mathrm{~Pb} & 54.0 \mathrm{~g} / \mathrm{l} \\ \text { 市販ホウフツ酸 } & 200 \mathrm{~m} l / l \\ \text { 添加ホウ酸 } & 25 \mathrm{~g} / l \\ \text { ペプン } & 3 \mathrm{~g} / l \\ \text { ヘイドロキノン } & 10 \mathrm{~g} / l \\ D_{K} 3 \mathrm{~A} / \mathrm{dm}^{2}, & \text { 浴温 } 30^{\circ} \mathrm{C}\end{array}$

第 8 図 浴中のスズ濃度の影響

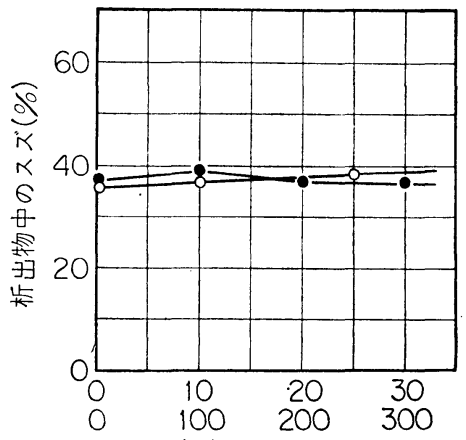

添加ホウ酸(gN)および市販ホウフッ酸( $\mathrm{m} / \mathrm{l} / \mathrm{l})$

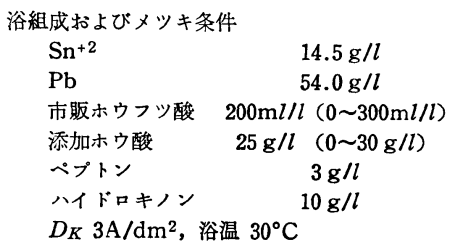

第9図遊離ホウ酸括よび ホウフッ酸の影響

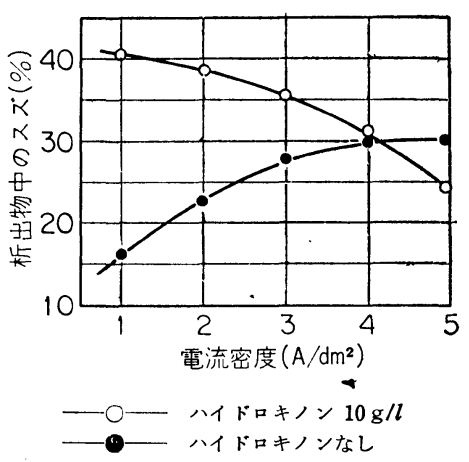

浴組成およびメッキ条件

$\begin{array}{lr}\mathrm{Sn}^{+2} & 14.5 \mathrm{~g} / l \\ \mathrm{~Pb} & 54.0 \mathrm{~g} / l \\ \text { 市販ホゥフツ酸 } & 200 \mathrm{ml} / l \\ \text { 添加ホウ酸 } & 25 \mathrm{~g} / l \\ \text { ペフトン } & 3 \mathrm{~g} / l \\ \text { ハイドロキノン } 0 \text { および } 10 \mathrm{~g} / l \\ D_{K} 3 \mathrm{~A} / \mathrm{dm}^{2} \text {, 浴温 } 30^{\circ} \mathrm{C}\end{array}$

第 10 図 電流密度の影響 
Vol. 17, No. 9, 1966

\section{$6 N$ 塩酸}

$3 N$ 酢酸ナトリウム溶液

BT 指示薬执よび PV 指示薬

\section{操作方法}

1）表面積約 $10 \mathrm{~cm}^{2}$ の鉛一スズ合金メッキ試料を， 80 〜 90ㄷ に加熱したハク離液約 $10 \mathrm{~m} l$ 中でメッキを完 全に溶解せしめる。

2) 試料を取出してのち, 0.05M EDTA 標準液 $50 \mathrm{~m} l$ を正確に加えてのち，メスフラスコを用いて正確に $100 \mathrm{~m} l$ に希釈する。これを正確に $50 \mathrm{~m} l$ づつに分 け，その各々の試料溶液で鉛とスズとを分析する。 一鉛の分析一

3）一つの試料溶液に 純水 約 $150 \mathrm{ml}$ と $20 \%$ トリエ夕 ノールアミン溶液 $5 \mathrm{~m} l$ を加え，スズをインペイした のち, $2.5 \mathrm{~g}$ の塩化アンモニウムを加えれば $\mathrm{pH} 10$ と なる。

4） BT を指示薬として, 過剩の EDTAを $0.05 \mathrm{M}$ 硫酸 覀鉛標準溶液で这滴定する。終点は試料溶液が黄色に 着色しているので, 緑色から赤色になったところであ る。

5) 計 算

この時の $0.05 \mathrm{M}$ 硫酸亜鉛の滴定 $\mathrm{m} l$ を $a$ とすれば, 試料中の鉛の重量 $A(\mathrm{~g})$ は

$$
A=0.01036 \times\left(\frac{50}{2}-a\right) \times 2
$$

一スズの分析-14)

6) いま一方の試料溶液に $6 N$ 塭酸 $5 \mathrm{ml}$ を加衣, 数 $\min$ 間加熱沸騰せしめる。これに純水約 $150 \mathrm{~m} l$ と $3 N$ サク酸ナトリウム溶液約 $20 \mathrm{~m} l$ を加えれば $\mathrm{pH}$ は約 5 となる。

7） $70 \sim 80^{\circ} \mathrm{C}$ に加熱し， PV 指示薬 $4 \sim 5$ 滴を加え， $0.05 \mathrm{M}$ 硫酸覀鉛標準溶液で熱時逆滴定する。終点は, 黄色が緑色になったときである。

8) 計 算

この時の $0.05 \mathrm{M}$ 硫酸覀鉛の滴定 $\mathrm{m} l$ を $b$ とれば, $(50 / 2-b) \times 2$ は鉛十スズに相当するので, 試料中の スズの重量 $B(\mathrm{~g})$ は

$$
B=0.005935 \times(a-b) \times 2
$$

となる。

9）ゆえに，析出物中の鉛拉よびスズの百分率は

$$
\mathrm{Pb} \%=\frac{A}{A+B} \times 100, \quad \text { Sn } \%=\frac{B}{A+B} \times 100
$$

となる。

鉛一スズメッキのハク離法としては, すでに発表され ているいくつかの方法" があるが，この場合には，上記 のハク離を使用した場合の方が便利である。○ーニトロ安 息香酸を使用した場合には，素地が黄銅の場合，素地金
属がいくらか侵されるので誤差を生じるが，銅および鉄 素地の場合にはそのようなことはない。エンストリップ TL の場合には, 黄銅, 銅抢よび鉄など, いずれの素地 金属であっても腐食されることはない。これらのハク離 剂を使用すると，いずれも黄〜黄カッ色に着色するが, 滴定の終点を妨害するようなことはない。経済的には, o-ニトロ安息香酸を使用するよりも，エンストリップ TI を使用した方がかなり有利のようである。また鉛一 スズ合金メッキは非常に柔らかいので，ナイフなどでメ ッキを削りとり, これを硝酸で加熱溶解してのち, 上記 （2－1）の方法に準じて分析してよい。

上記分析操作法中, 鉛の分析はスズの分析に比べ簡単 であるのと，素地金属は溶解せず，鉛一スズ合金メッキ が溶解されるのを利用し， $A+B$ は, メッキを溶解した 前後の重量差より求め, 鉛のみを上記の 分析法で分析 し， $(A+B)-A$ で，スズ $B$ を求めてもよい。

これらの方法による分析結果は, 鉛とスズの電気化学 当量の差を利用した電解法による析出物の 組成の決定 法，および重量法で求めた組成とよく一致した。

この他にも EDTA を利用する方法で, 鉛 +スズを XO を指示薬として, 過剩の EDTA を鉛溶液で滴定し たのち，これにフッ化ナトリウムを加え，スズとキレー トした EDTA を遊離せしめ，これをさらに鉛溶液で滴 定する方法 ${ }^{15)}$ もあが，この場合には良好な結果を示さ なかった。

\section{3-2 鉊一スズ合金メッキの平均厚サ測定法}

メッキの平均原サは

$$
T=W / k C
$$

で表わすことができる。この場合の $T$ はメッキの厚サ (a)，Wはメッキの重量 $(\mathrm{g}), C$ は試料の表面積 $\left(\mathrm{cm}^{2}\right)$ であり, $k$ は金属の種類により定まる定数であり,金属の 比重と単位の換算を含んだものである。スズ拉よび鉛メ ッキの場合には，それぞれkは0.00073 和よび 0.00113 となる。これら両者の合金メッキでは, 合金の組成によ り，その比重が直線的に変化するものとすれば, 鉛のあ る\%(たとえば $D \%$ ) に和いては，その係数 $k^{\prime}$ は

$$
k^{\prime}=0.00073+0.0004 \times \frac{D}{100}
$$

となる。ゆえに，この場合のメッキの厚サ $T$ は

$$
T=\frac{A+B}{\left(0.00073+0.0004 \times \frac{D}{100}\right) C}
$$

で表わすことができる。この方法で, 幅 $60 \mathrm{~cm}$ の帯鋼に 連続メッキ装置により鉛一スズメッキした試料の厚サを 測定した場合と，顕微鏡により測定した值とはよく一致 した。 


\section{4. おわりに}

ホウフッ化鉛一スズメッキ液中の鉛は, EDTA により 簡単にしかる迅速に分析することがでさる。また従来か ら，いろいろ問題となっていた遊離ホウフッ酸，避離木 ウ酸扰よびハイドロキノンの分析法を確立した。

鉛一スズ合金析出物中の 各成分も， EDTA で簡単に 求めることができる。これらの方法は，実際に現場で木 ウフッ化鉛一スズメッキ浴を管理されている人達にとっ ては非常に有効であると確信する。(1966.5.16 受理)

\section{文献}

(1) A. Brenner, Electrodeposition of Alloy, II, p. 4 (Academic Precess)

（2）土肥，本誌招よび Metal Fnishing 飞投稿中

(3) K. E. Langford, Analysis of Electroplating and
Related Solutions, p. 97 (Second Edition)

(4) A.K. Graham, M. B. Diggin, Electroplating and Engineering Handbook, p. 251

(5) F. A. Lowenhein, A. H. DuRose, W. Blum, Modern Electroplating, p. 251(Second Edition)

（6）上野，キレート滴定法，p. 293

(7) K. E. Langford, Ibid., p. 278

(8) K. E. Langford, Ibid., p. 68

(9) A. G. Gray, A. H. DuRose, W. Blum, Modern Electroplating, p. 288 (First Edition)

(10) F. A. Lowenhein 5, Ibid., p. 244

(11) A. G. Gray 5, Ibid., p. 421

(12) J. B. Mohler, Iron Age, 169, Feb. 7, 139 141 (1952)

(13) JIS K 8738

(14) J. Jankovsky, Collection, 22, 1052 (1957)

(15) L. T. Ottendorfer, Chemist-Analyst, 47, 96 (1958)

\title{
パフ研摩の自動化に関する講演会
}

\author{
主 催 金属表面技術協会 \\ 企 画 金屋表面技術協会 研摩部会 \\ 期 日 昭和 41 年 10 月 18 日（火）午後 1 時より \\ 場 所 日本化学会 会議室 \\ （国電「打茶の水駅」下車徒歩 3 分 明大大学院 5 ら) \\ 会 費 無 料 \\ 䜅演 \\ 1. バフ研摩の自動化について…………………光陽 研磨材（株）遠藤幸雄 \\ 2. ハモンド製自動バフ研摩機について…………....林 捨次郎商店永田㬰 \\ 3. 自動バフ研摩機について……………………....株) 中 央 製作所 江 口 寿 \\ 4. 自動バフ研摩機について……………………..(株)野水機械製作所 野 水 博 司
}

